\title{
Discussion on Teaching Business Japanese Demand for Talent in the Business Environment
}

\author{
Wang Shanshan \\ Foreign Language Department \\ Jilin Business and Technology College \\ Changchun, China \\ 182076127@qq.com
}

\begin{abstract}
On since the 1990s, with the strengthening of SinoJapanese trade relations, business Japanese education ushered in an unprecedented upsurge, training a large number of Japanese business people. With the further development of economic globalization, the business activities of both China and Japan will be more closely and frequently, all kinds of opportunities and challenges will lead to the teaching reform of business Japanese in our country. In view of the problems existing in the traditional business Japanese teaching, after the business Japanese teaching will pay more attention to comprehensive training of language ability and professional ability, the ability of cross culture communication, students are more willing to take part in all kinds of business activities, business knowledge and experience accumulation.
\end{abstract}

Keywords-teaching mode; classroom design; an analog implementation; Intercultural Communication

With the deepening of China's economic development and opening up of the domestic market, the Sino-Japanese economic and trade relations has been rapid development, China has become Japan's largest trading partner. Meanwhile, Japanese investment in China despite the rapid growth trend in recent years has eased, but the utilization of foreign investment in China still occupies an important position, its investment accounted for the proportion of China attracted a total stabilized at around $10 \%$, the country first. China economic and trade related units need a lot of well-known trade knowledge or familiarity comprehensive domestic business environment of the Japanese business people; on the other hand, political relations between China and Japan has changed greatly, Japan from blindly follow the American policy, to seek establish long-term and stable Sino-Japanese relations in the direction of change. Together with the January 2008 release of the new labor contract law and business cost impact of corporate income tax rate and other laws and regulations, more Japanese enterprises for business personnel requirements, and show the trend of diversification, specialization and Advancement. This Japanese business education presents new challenges for business Japanese language education was given a new mission of the times.

This paper attempts to date from the actual needs of the business community for business professionals starting to explore new ideas in the New Era Business Japanese Teaching binding status of Japanese business education writer in Shanghai Institute of Foreign Trade is engaged.

\section{The Present Situation of Business Japanese Teaching}

Learning and research in all languages actually contain sociability issues and information issues; it helps to learn the language and different cultural backgrounds to communicate. Enough information for an accurate understanding of the meaning of language use is indispensable, but which we often lack sufficient knowledge. In China, business Japanese courses Settings late (mainly starting in the 1990s), and the direction of emphasis on culture teaching business language proficiency, so there are still a lot to be desired.

\section{A. Mainly in the classroom teaching mode}

Beginning in the 1990s, a large number of Japanese companies to enter China, the Sino-Japanese economic exchanges become more frequent. In order to meet the needs of business Japanese talent, the country with Japanese universities and professional schools have opened part of Japanese business Japanese courses, ranging from teaching business Japanese speaking, listening, correspondence, negotiating skills, but basically writing materials for Lord, still teaching methods teachers on students passively accept the "spoon-fed" teaching mode. In fact this situation is not conducive for business students interested in Japanese, hindering the students and teacher autonomy and exchange practical applications, often leads to considerable period of time after graduation can't enter the role immediately[1].

\section{B. Externally oriented teaching content}

Business Japanese education started late, the relevant theoretical research is still in its infancy, education or business Japanese business Japanese researchers definition of the different opinions, has not been determined, it did not identify the unity and authority of the business aspects of Japanese Textbooks. General Business Japanese tends to understand the main externally oriented. The fact is, we have to admit that foreign trade is one of the business activities of the content, but in addition, direct investment and foreign economic cooperation, business and management, mergers and acquisitions, logistics, shipping, finance, etc. are foreign an important part of business. Moreover, with the use of national adjustment policies and foreign investment industrial policies, the Japanese business focus of the work has changed. So, we have for the "Business" and "Business Japanese" it is necessary to expand the teaching content, so as to better improve the 
practical effect of preventing the students' knowledge structure and social needs of occurrence of touch.

\section{Lack of teachers}

Whether it is to improve the teaching quality and teaching materials, the key is to have a satisfactory business Japanese educators' team, namely: not only have the Japanese language skills and rich experience in teaching, but also need to have enough business experience and knowledge. But now, due largely accepted college teachers themselves are purely Japanese education or halfway "monk", the domestic lack of teacher training in this area educational institutions, foreign universities to learn and there are not professional docking and many other issues, resulting in domestic business Japanese teacher team appeared teachers themselves lack business experience embarrassment[2].

\section{The Demand For TALENT IN Business CiRCLES OF ChinA AND JAPAN}

In today's world, we from the "business" activity-based stepped into the 20th century by the "world factory" to "world R \& D institutions" advance the post-WTO era, the weight of the modern service industry in the country's economic structure increasingly heavy , financial and trade services in the future may be dominated by an important pillar industry of macroeconomic performance, particularly in Shanghai this city and strive to build a large international economic, trade, financial and shipping center even more four. Therefore, the changes of the times and social development given the connotation and denotation, teaching a new business language skills, "business" is also placed new expectations and mission. These generally reflected in the Japanese business culture is as follows:

\section{A. Language proficiency requirements}

Language is the carrier of information transfer, not a foreign language or foreign language skills that are less obviously lose a lot of business opportunities. In international business activities, in order to overcome language barriers, companies tend to hire interpreters to convey information. But the role of the translator is limited, such as: the company's information may be filtered out, is not transmitted to each other, or be misinterpreted; hire translators who betray likely cause irreparable damage. Japanese businessmen usually prefer to establish personal relationships with business partners, so if the clerk both business facilitator while proficient in Japanese business, it will be more conducive to the development of emotional culture and business trading partners.

\section{B. Business capability requirements}

Language is a tool to create information, and information is the life of the source language. Therefore, qualified international business workers not only have extraordinary foreign language skills, but also require the ability to accurately express and impart information, and formal education plays a key role in the ability of these cultures. In terms of education, it should be a Japanese, business knowledge and skills in the learning process. At present, the Department of Japanese or
Japanese professional colleges and universities nationwide, as an authorized examination means the ability of Japanese students in addition to the domestic Japanese professional four or eight Test and Japanese Language Proficiency Test in Japan, but from 2008 onwards, including Shanghai seven cities in China implemented a BJT (business Japanese Proficiency test), which fully shows the desire of the Japanese business Japanese business people, but also for China business Japanese education is proposed to strengthen the training of specialized personnel hope.

\section{Intercultural communication skills training requirements}

Develop international business activities, the first business communication, and its first step is cross-cultural communication. Such as: According to January 2008 began to implement a new "Labor Contract Law", the contract of enterprises and employees of at least two years, so the Japanese-funded enterprises on the one hand cautious hiring local employees, improving conditions of employment, on the other hand, actively training local employees of enterprises belonging to prevent the brain drain. This is like using the "quit" means to sharpen the experience of China in order to seek higher income employees, the greater the potential for conflict, and to move beyond the "crash" of thinking mainly depends on the two sides to deepen cultural and other values understanding[3]. In addition, with the improvement of the flow of talent liberalization, the staff of the same enterprise may come from different cultures around the world, enterprises in order to create a harmonious atmosphere in the interior, the general staff will be asked to acknowledge and agree with these diverse cultures. This requires that the staff should have a certain degree of cross-cultural communication skills.

\section{Business JAPANESE TEACHING MODE CONSIDERATIONS}

Based on the above analysis, I believe: Business Japanese teaching itself, there is the inherent requirement of the times, Japanese business has a pivotal position in China's foreign business activities. But the current teaching model in terms of lateral (knowledge span) or vertical (depth), are still in its infancy. Category Business Japanese linguistics from speaking, belongs to the study of applied linguistics, but from a business point of view is a connotation of economic, trade (including trade and trade in goods and services), investment and other comprehensive, interdisciplinary type course, business Japanese so we can give this definition: Japanese business is built on the basis of applied linguistics, interdisciplinary, refers to the commercial economy, trade, investment and other language applications, is one of the important means to carry out business activities, it aims to cultivate three kinds of skills: business skills, verbal communication skills and cross-cultural communication skills. Here we focus on this definition, conduct a probe into the teaching mode, teaching staff construction of two aspects.

\section{A. Teaching Model}

In international business practices in recent years, the author notes that such a widespread phenomenon, both Japanese professional or trade after graduation engaged in international business people in new jobs, generally go through 
more than six months "familiar period "or" adjustment period. " During this period, new employees on job content curiosity soon disappear, replaced by the specific aspects of the work are not familiar with or not suited to generate a loss, fear, or even suspect that he learned in school or on the usefulness of knowledge his intelligence and ability to generate doubt. How to help students succeed through this period is the central task of Business Japanese education. I believe that the key to the Teaching Mode Design and Social docking is to solve the problem[4].

\section{1) Class Design}

Classroom design is one very important part of the teaching process, which includes class schedule, course content, teaching methods and means. Successful classroom design should not only fully reflects the purpose of teaching, but also to combine teaching content, and can stimulate students' enthusiasm for learning, classroom design full of fun, diversity. Since the focus of the university teaching business Japanese are different, so the design is different class. Here we combine teaching characteristics of Japanese business school for business class Japanese design resolution.

\section{a) Design teaching content}

Design of teaching content and syllabus must first consider the consistency, both to reflect the purpose of teaching, but also combines period features, highlighting the practical value. The purpose of teaching Business Japanese is: cultivate Japanese solid foundation, to master business Japanese listening, speaking, reading, writing, translation and other comprehensive skills, familiar with international business environment and related basic knowledge and understanding of China's economic development as well as Japanese food, housing, cross-cultural communication and other cultural knowledge, proficient in Japanese business negotiations, international business activities, the work of competent international business talents. About the purpose of teaching, teaching materials our school is divided into six large blocks: Immigration articles, life articles, financial articles, investment and development articles, business articles, and business correspondence papers. Of course, since the rich "commercial" content, wide, and is a discipline with a strong dynamic development, the teaching materials should be ready to make some adjustments or additions. All in all, a successful design teaching content must fully reflect the characteristics of the times, the only way to better reflect the purpose of teaching us to achieve practical business Japanese. Of course, when you set up the teaching content, it must be focused, avoid exhaustive, pointless.

\section{b) Teaching methods}

Teaching methods are reasonable direct impact on the effectiveness of teaching. So when setting teaching methods and means, first of all to ensure the dominant position of the guiding status of teachers and students, again considering course content interesting and flexible teaching methods, students learn business Japanese sufficiently stimulated interest and enthusiasm, the formation of teachers benign interaction with the students. For example: We have opened a Japanese business network teaching platform. Students can visit the platform of the program-related information and content, and can use the platform discussion forum exchanges of teachers and students, and between students, improve network resource utilization effect in teaching. In addition, the platform also provides students with the course related to the reference site, through these relevant site visits, expanding students' knowledge, to enhance students' understanding of the full range of aspects in Japanese society, culture, economy and trade, etc., to improve students' independent analysis of issues and problem-solving skills.

\section{2) The second class}

Create and provide a good second class of students for students language skills, thinking skills and improve crosscultural communicative competence can play the role of two birds with one stone. Namely enhance learning in practice and improve the ability to practice in the study.

(1) Fully tap the internal and external resources, such as Japanese teachers, Japanese students, school students, and actively carry out the Japanese Corner, Japanese Speech Contest, Song Contest Japanese, Japanese comedy skits, Japanese writing contest to promote the tea ceremony, ikebana, kimono, etc. Sino-Japanese cultural exchanges to enrich students' spare time, to further improve the communication skills of students. (2) Invite owned business leaders and wellknown Japanese business and Japanese experts to lectures, so that students experience of face to face contact at the same time, understanding the needs of society and establish their own goals in life, to stimulate students' curiosity. (3) Extensive contacts with Japanese companies, institutions predominating relevant units to establish training base for students practice time to vacation or business trainee. Promoting the Practice Base not only refined the students' hands-on experience, but also to build a bridge for students' job search activities.

Business Japanese education in China today is in a stage of rapid development, business Japanese language education should be the aim of maximizing mining and mobilize students 'learning potential, and constantly improve, and improve students' comprehensive ability, so that students find confidence in learning, to find the target for students' work, as well as future career development to create favorable conditions[5].

\section{B. Strengthen the teaching staff, focusing on the development of intercultural communication skills}

Teachers in the dominant position in the teaching process, improve its own ability can't be ignored. As most Japanese business background is in Japanese professional teachers, basic business knowledge from books, this lag "to sell off now" teaching methods will affect the quality of teaching business Japanese, how to strengthen the construction of teachers business Japanese business Japanese have become workers face the issue.

\section{1) Cultural Quality}

Development of intercultural communication skills of its essence is the cultural qualities of culture. 21st Century Business Activities intercultural communication skills more and more attention, as Business Japanese teachers should provide students cross-cultural business communication skills 
to learn and master play a positive role in guiding. But due to the student in the learning process of cultural and language input mainly from textbooks, and classroom teachers to teach Japanese, so Japanese teacher of Japanese language and cultural training is particularly important. Japanese professional teachers must first in-depth and detailed understanding of Japanese history, culture, traditions, customs, lifestyle, current affairs, etc. We should correctly handle the relationship between language teaching and culture teaching; good at helping students improve cross-cultural communication awareness and communication process to avoid the misuse of cultural phenomenon. In addition, the use of spare time or teaching network for students to add some covering politics, economy, culture, science, the difficulty of appropriate books, expanding student Japanese vocabulary in political, economic, cultural and other help students systematically study Business Japanese at the same language, understand and master the Japanese national culture, history, customs and traditions, so as to remove obstacles in the future cross-cultural communication[6].

\section{2) Business accumulated practical experience}

Since Japanese business itself is an application category, so the teacher's own business experience is very important. First, teachers should actively participate in business activities, business Japanese accumulation of knowledge and experience. When teachers attend a business should make full use of its advantages. Business Japanese teachers have a common advantage that a higher Japanese listening, speaking, reading, writing and translation capabilities. Therefore, the use of these capabilities in interpretation, translation and other business aspects of the work is the accumulation of business experience shortcuts. In addition, in the environment full of business opportunities seize the right time involved in the actual business activities of Japanese educators' shortcut for a business can be considered.

\section{CONCLUSION}

Global economic integration is to further deepen the two sides of the business activities become increasingly frequent and increasingly close business contacts, the challenges of the new era and the unique friction ensued. How to cultivate a common type of Japanese business people to engage in the future both in the work of the Japanese government, institutions or enterprises, but also representative offices in Japan, institutions and enterprises, as well as business activities between the two countries and Japan contribute to the lasting friendship, in large part due to continually explore new ideas business Japanese education. I believe that, on the basis of long-term teaching practice, listen to the views of the two sides of insight to design a set of effective Business Japanese teaching model, strengthening the teaching staff is a priority. On this basis, and actively promote the integration of Japanese business knowledge and depth of reform, will be built into a Japanese business in a unique style of teaching, knowledge mastery, student employment is widely accepted social discipline. As long as we teach, learn two ways to work together, I believe this day is not far off whom.

\section{REFERENCES}

[1] Shi L. A Brief Discussion on the Reform of Business Japanese Teaching Based on the Requirement of Talents for Foreign Trade[J]. Science Education Article Collects, 2013.

[2] Lou Y Q. On Introducing Japanese Corporate Culture into Business Japanese Teaching[J]. Value Engineering, 2014.

[3] Gu Jiazu. Cross-cultural communication: the covert culture in foreign language literature[M].Nanjing:Nanjing Normal University Press, 2000.

[4] Wu Ting. The importance of cultural introduction to foreign language teaching class[J]. Japanese Study and Research,2000(1).

[5] Wu Yimin,2010. Practice and exploration of action-oriented mode in the series of business Japanese courses-Centering on the project teaching method[J]. Journal of Guangzhou City Polytechnic(2).p:96-100

[6] Zhao Y. Application and Research on Curriculum Reform System of Theory and Practice-based Integration[J]. Guide of Science \& Education, 2012. 